\begin{tabular}{|c|c|c|}
\hline $\begin{array}{l}\text { EXCELLENT } \\
\text { PUBLISHERS }\end{array}$ & $\begin{array}{c}\text { International Journal of Current Research } \\
\text { and Academic Review } \\
\text { ISSN: 2347-3215 (Online):,; Volume } 5:, ; \text { Number } 9 \text { (September-2017) } \\
\text { Journal homepage: http://www.ijcrar.com }\end{array}$ & 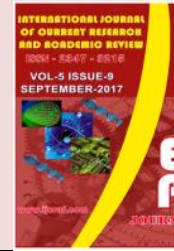 \\
\hline
\end{tabular}

doi: https://doi.org/10.20546/ijcrar.2017.509.001

\title{
An Overview of Environmental Pollution Management in Tanning Unit
}

\author{
Rita Jayaraj* \\ Department of Zoology, Stella Maris College (Autonomous), Chennai, Tamil Nadu, India \\ *Corresponding author
}

\begin{abstract}
Leather industry is one of the oldest industries and also highly polluting industry in India. Tanning industry in India stands among the five top exports oriented industries. The unplanned growth of the leather industry, inadequate knowledge and inexperience in environment pollution management has caused several pollution problems which are yet to be solved at the desired level. In the present study a sincere attempt is made to cover all the important aspects relating to environmental pollution problems associated with this industry. In the present study, results have demonstrated that mostly all the stages of leather processing, individually and collectively have an impact on the environment. The quantity of chemicals used for processing, details of wastewater discharge processing capacity, and characteristics of wastewater released in various pre-tanning processes, characteristics of effluent from tannery have been studied. The treatment of liquid wastes generated by the Tanning unit has also been highlighted.
\end{abstract}

\section{Article Info}

Accepted: 30 August 2017

Available Online: 20 September 2017

\section{Keywords}

Wastewater, Tannery effluent,

Pollution load,

Treatment of tannery wastewater, Pollution

\section{Introduction}

Tamil Nadu is one of the largest producers of finished leather in the country. There are more than 1000 tanneries classified under Small Scale industries processing about 2 tons of hides and skins per day. There are eight major tanning clusters, located in Tamil Nadu viz., Ranipet, Ambur, Pernampet, Vaniyambadi, Erode, Dindugul, Trichy and Pallavaram. Tannery effluents are the most pernicious, offensive and deleterious of all industrial wastes that have posed a potent threat to environmental pollution. (Ros and Ganter1998) They contaminate air, surface and sub-soil waters and undermine the fertility of the soil. As a result of rapid strides taken by the leather industry, the menace of environmental pollution has assumed colossal proportions. The disposal of tannery wastes is the responsibility of the tanning industry. (Kadam, 1987) But the cost involved in their disposal according to specifications and regulation is beyond the resources of the industry. Due to industrial expansion, large quantities of industrial wastes are accumulating in environment and cannot be disposed without prior special treatments. Due to industrial enlargement, massive quantities of industrial wastes are accumulating in environment and can't be disposed while not previous special treatments (Belay, 2010). In particular, waste products from the mining and metal refining industries, sewage sledges and residues from power station and waste incineration plants can contain heavy metals at high concentrations.

Usually, these heavy metals can be leachated from the soil to the surface water system (Chang et al., 1984; Dowdy et al., 1991) at concentrations higher than they are allowed (CEC, 1986). Effluent disposal into the environment creates adverse effects by altering the normal physiochemical properties of soil and water (Kannan et al., 2012). 
Tannery effluents are of large scale environmental concern because they color and diminish the quality of water bodies into which they are released. Among heavy metals presents in sludge, Chromium is one of the most common. This metal exists in two stable oxidation states, trivalent and hexavalent Chromium. The trivalent Chromium state is less toxic and mobile, while hexavalent Chromium is easily soluble and 100 fold more toxic than trivalent Chromium. So, the reduction of Chromium (VI) to Chromium (III) is an attractive and useful process for remediation of Chromium (VI) pollution, and the technologies focusing on transformation of Chromium(VI) to Chromium(III) have accordingly received much more concerns (Vijayanand et al., 2012). Tannery wastewaters are stratified because the highest pollutants among all industrial wastes. They are particularly giant contributors of Chromium pollution.

\section{Materials and Methods}

The water samples have been collected from the outlet of the tannery unit. In this present study, various physical and chemical parameters of water samples were determined using APHA (1998) Standard methods for the examination of water and waste water. The samples collected were analyzed for important physical and chemical parameters such as $\mathrm{pH}$, alkalinity, acidity, BOD, COD, Chlorides, Total solids, suspended solids, and sulphate were determined using standard procedures. Also the above parameters were measured in waste water of the tanning process, such as- Soaking, Liming, deliming, Pickling, Chrome tanning, Neutralisation and dyeing processes. All the chemical constituents are expressed in $\mathrm{mg} / \mathrm{L}$ (milligrams/liter).

\section{Results and Discussion}

Sodium chloride, Lime, Sodium sulphide, Ammonium chloride/Ammonium sulphate, Bate powder/ sulphuric acid, Basic chromium sulphate, vegetable tan extract, sodium sulphate, sodium carbonate, Sodium formate, pretanning syntax, syntax for retaining, fat liquor, dyes.

Solvents like trichloroacetic acid, kerosene, the quantum of chemicals used for processing $10,000 \mathrm{kgs}$ of skins per day are shown in Table 1

Beam house operations include, Soaking, Liming and Deliming process. The principal raw materials used in tannery are hides and skins and they are received in wet salted or dry salted conditions. Soaking process consists of immersing the wet salted or dry salted hides and skins in water in pits for 6 to $24 \mathrm{hrs}$. In some tanneries wetting agents are also used during soaking. Nowadays some of the tanneries use either paddles or drums for the soaking process to reduce the duration of soaking and to economize the water consumption.

With regard to Water discharge it should be understood that the Tanning industry is one of the major industries consuming large quantity of water for processing of raw materials into leather. Tanneries draw water from their own wells and from river banks through tankers. Water used in the process are not measured. Since unskilled labourers are employed for beam house operations (for which pits are used), water consumption is more than for tanning and post-tanning (for which drums are used). Operations which include consumption of water for different sectional operations are given in Table 2.

Beamhouse operations consume $55 \%$ of total water while tanning and post tanning operations consume $45 \%$ of total water. As indicated in Table 3 the water used in different types of processinvolve batch operations and therefore waste water discharge from tanning industry is not a continuous flow, instead it is only an intermittent discharge. Figure 1 shows the Discharge pattern in Tanning industry. Water usage for leather process varies from tannery to tannery, region to region and also from season to season.

Characteristics of Effluents, include Soak Liquor Characteristics-Soak effluent is characterized by $\mathrm{pH} 7.35$ to 7. It has high suspended solids in the effluent.It comprises of suspended impurities like dirt, dung and soluble material like blood adhering to the hides and skins during soaking; the salinity of the soak liquor is very high. The $\mathrm{pH}$ of the soak liquor is favourable for the growth of bacteria and hence the liquor undergoes putrefactionvery rapidly. Characteristics of soak liquor is given in Table 4.

In Liming effluent -Lime liquor contain suspended and dissolved lime and sodium sulphide. It is highly alkaline and is one of the heaviest of the fractions in terms of biochemical oxygen demand and suspended solids. This waste may contain high concentration of sulphides when sodium sulphide is used in the liming process. Also, the Unhairing and fleshing effluent is equally polluting, since this effluent from the unhairing operation contains mostly hair and sulphides. Fleshing operations discharges effluent with fatty and fleshy matter in suspension. The Deliming effluent -Spent deliming 
liquors that are discharged carry a significant pollution load in terms of BOD. In terms of Spent bate liquor, it should be noted thatthis waste contains a high amount of organic matter and ammoniacal nitrogen due to the presence of soluble skin proteins and ammonium salts used in bating. BOD is usually low. The Spent Pickle Liquor also carries a high amount of chloride and the waste is acidic.

To highlight Vegetable tanning effluent- the spent vegetable tan liquor is the strongest sectional waste in a composite tannery effluent.It has persistence of colour which is difficult to remove by chemical or biological method and a characteristic offensive odour. This is acidic in nature.

When it comes to Chrome tanning effluent it is imperative that the spent chrome tan liquor is greenish in colour and is highly acidic and this effluent contains a high amount of trivalent chromium.

However, the Dyeing and fat liquoring effluentis smaller in volume. The major constituents are dye and oil emulsions. Finally, the Composite effluentfrom a tannery is highly coloured and foul smelling. This includes lime, sulphide, soluble protein, fats, grease, chlorides, tannins, chromium sulphate, hair, flesh particles, bacterial inhibitors, wetting agent, oils, salts and dyes.

When it comes toPollutional load of the tanning unit, as is shown in Table 5. It is indicative that tanning unit discharges inorganic, non-degradable salts, in the form of $\mathrm{Cl}^{-} \mathrm{SO}^{2-}{ }_{4}, \mathrm{Cr}^{3+}, \mathrm{S}^{2-}$

These pollutants are thrown out as dissolved solids causing ground water pollution. It has been observed that the treated tannery effluents bear a straw yellow to light orange which are not aesthetically accepted despite the organic pollution being eliminated to the required level.

\section{Treatability of waste water}

Biodegradability of waste constituents are assessed by the ratio of $\mathrm{BOD} / \mathrm{COD}$. This is considered to be biodegradable index of wastewater. This ratio determines treatability of waste water either by chemical or biological means. In Table 5, the BOD/COD ratio of different sectional wastes is shown. The BOD/COD ratio of wastes from finishing operations is less than that of Beamhouse wastes. Even though BOD/COD ratio of beamwaste is above 0.5 , but due to presence of high amount of ammonium chloride, biological activity is inhibited. Chlorinated phenols are important compounds to be investigated due to the various mixtures used in the tanning industry and their ecotoxicity potential (UNEP 1994).

Vegetable tannins are also used to retan leather to impart certain specific desired. Pollutional load contribution by different sectional wastes to Beamhouse waste thereby leading to composite waste is shown in Table 5. It would be highly illuminating to project that pollutional load by Beamhouse wastes are more than Tanning and Post Tanning operational water. Among beamhouse wastes, liming alone contributes $47 \%$ of $\mathrm{Cl}^{-}$Total composite. Presence of sulphides in the effluent retard rate of degradation of organics by aerobic organisms. The major contribution of sulphide to composite effluent is only through lime yard effluent.

Hence it is worth mentioning to segregate the sectional waste from the other-main-streams to be evaporated in solar evaporation ponds and scraped salts are disposed in sea. Alternatively the entire composite waste water after Physical, Chemical and Biological treatment may be treated. Physical and chemical processes are frequently employed to treat contaminated sites, but often do not destroy contaminants (Bouwer et al., 1994).

Further Reverse Osmosis was used to remove the chloride such that to reach the effluent discharging standard. This modification of procedure may be technically viable, but the cost involvement is very high and also this technique demands a very trace level of organics in the wastewater which becomes highly impracticable due to certain environmental constraints.

Salinity or ionic strength can cause a small decrease in the solubility of non-polar organic compounds (e.g. naphthalene, benzene, toluene etc.) through a process known as the salting-out effect (Pepper et al., 1996). In a study in Egypt, $\mathrm{NaCl}_{2}$ concentration varied between 40,000 and $50,000 \mathrm{mg} \mathrm{L}$ in the effluent discharge in a tannery under study (Hafez et al., 2002).

\section{Treatment of tannery waste water}

The following unit operations are employed for the treatment.

Equalisation cum settling tank/primary clarifier.

Anaerobic lagoon

Aerated Lagoon

Secondary settling tank/secondary clarifier. 
Table.1 Quantity of chemicals used for processing 10,000kgs of skin/hide

\begin{tabular}{|l|c|c|c|}
\hline Chemicals & Raw to finish & Process Raw to E.I & E.I to Finish \\
\hline $\mathrm{NaCl}$ & 80 & & \\
\hline $\mathrm{Lime}$ & 600 & 600 & \\
\hline $\mathrm{Na}_{2} \mathrm{~S}$ & 30 & 25 & \\
\hline $\mathrm{Soda}$ ash & 2.5 & & \\
\hline $\mathrm{Na}_{2} \mathrm{SO}_{3}$ & & & 20 \\
\hline $\mathrm{NaOH}^{\mathrm{NH}_{4} \mathrm{SO}_{4}}$ & 2.5 & 2.5 & \\
\hline $\mathrm{Wetting} \mathrm{agent} \mathrm{H}_{2} \mathrm{SO}_{4}$ & 10 & 10 & \\
\hline Basic Chromium Sulphate & 2.5 & & \\
\hline Sodium formate & 10 & & \\
\hline Sodium Bicarbonate & 80 & & \\
\hline Syntan & 20 & & \\
\hline G.S. Powder & 10 & & \\
\hline Formic acid & 20 & & \\
\hline Fat liquor & 180 & & \\
\hline
\end{tabular}

Table.2 Details of Wastewater Discharge Processing Capacity: 10,000 skins /day weight of each goat skin: 0.8 to $1.2 \mathrm{~kg}$

\begin{tabular}{|l|l|l|}
\hline S.No & Operation & Wastewaterdischarge (inm ${ }^{3)}$ per day \\
\hline 1 & Beamhouse operations & \\
2 & Soaking & $80-90$ \\
3 & Liming & $55-60$ \\
4 & Fleshing & $32-38$ \\
5 & Washing before delining & $20-24$ \\
6 & Delining and bating & $9-10$ \\
7 & Scudding operation & $2-3$ \\
8 & Degreasing & $30-35$ \\
9 & Tanyard operations & \\
10 & Pickling & $5-6$ \\
11 & Chrome tanning & $18-22$ \\
12 & Washings & $10-11$ \\
13 & Neutralisation & $5-11$ \\
14 & Washings & $8-10$ \\
15 & Dyeing and fat liquoring & $5-7$ \\
\hline & Washings & $8-10$ \\
\hline & Floor washings & $40-50$ \\
& & $\mathbf{3 4 0 - 4 0 0}$ \\
\hline
\end{tabular}


Table.3 Characteristics of wastewater in $\mathrm{mg} / \mathrm{L}$

\begin{tabular}{|l|l|l|l|l|l|l|l|}
\hline Parameter & Soaking & Liming & Delming & Pickling & $\begin{array}{l}\text { Chrome } \\
\text { tanning }\end{array}$ & Neutralisation & Dyeing \\
\hline $\mathrm{pH}$ & 7.568 & $12-12.8$ & $7.1-9$ & $2.5-4.3$ & $3.5-4.1$ & $4.2-6.9$ & $3.9-4.5$ \\
\hline Alkalinity & 1150 & 19250 & 950 & - & - & - & - \\
\hline Acidity & - & - & - & 575 & 4800 & 1050 & 1550 \\
\hline BOD & 1200 & 1100 & 850 & 525 & 850 & 900 & 1650 \\
\hline COD & 2800 & 23000 & 1900 & 1850 & 3000 & 4500 & 3900 \\
\hline Chlorides & 6000 & 2850 & 6500 & 33500 & 10500 & 1250 & 2000 \\
\hline Total solids & 29500 & 15000 & 7950 & 60500 & 66000 & 15500 & 19000 \\
\hline $\begin{array}{l}\text { Suspended } \\
\text { solids }\end{array}$ & 5000 & 1075 & 2050 & 5000 & 2750 & 1500 & 1450 \\
\hline Sulphate & 625 & 0.470 & 800 & - & & - & - \\
\hline BOD/COD & 0.428 & & 0.447 & 0.283 & 0.283 & 0.200 & 0.423 \\
\hline
\end{tabular}

Table.4 Daily Pollution Discharge Details

\begin{tabular}{|l|l|}
\hline Parameters & Total Pollutional load in kgs/day \\
\hline COD (Total) & $1500-2200$ \\
BOD (Soluble) & $1100-1500$ \\
BOD (Total) & $630-930$ \\
Total Solids & $44-670$ \\
Dissolved solids & $5900-8500$ \\
Suspended solids & $5200-7000$ \\
Chloride & $740-1500$ \\
Sulphide & $1500-2400$ \\
Sulphate & $20-30$ \\
Chromium & $480-780$ \\
Phosphorus & $20-30$ \\
Nitrogen & $2-7$ \\
Dried sludge with 50\% moisture & $110-190$ \\
Volume wet sludge with 98-99\% moisture & $50-80 \mathrm{~m}^{3}$ \\
\hline
\end{tabular}


Table.5 Characteristics of effluent from Tannery

\begin{tabular}{|l|c|c|c|c|c|c|c|}
\hline \multicolumn{1}{|c|}{ Parameter } & Soaking & Liming & Delining & Pickling & $\begin{array}{c}\text { Chrome } \\
\text { Tanning }\end{array}$ & Neutralisation & Dyeing \\
\hline pH & 7.568 & $12-12.8$ & $7.1-9.0$ & $2.5-4.3$ & $3.5-4.1$ & $4.2 \cdot 6.9$ & $3.9-4.5$ \\
\hline Alkalinity & 1150 & 19250 & 950 & & & & \\
\hline Acidity & - & - & - & 575 & 4800 & 1050 & 1550 \\
\hline BOD & 1200 & 1100 & 850 & 525 & 850 & 900 & 1650 \\
\hline COD & 2800 & 23000 & 1900 & 1850 & 3000 & 4500 & 3900 \\
\hline Chloridies & 6000 & 2850 & 6500 & 33500 & 10500 & 1250 & 2000 \\
\hline Total Solids & 29500 & 28000 & 7950 & 60500 & 66000 & 15500 & 19000 \\
\hline Suspendend Solids & 5000 & 15000 & 2050 & 5000 & 2750 & 1500 & 1450 \\
\hline Sulphate & 625 & 1075 & 800 & & & & \\
\hline BOD/COD & 0.428 & 0.470 & 0.447 & 0.283 & 0.283 & 0.200 & 0.423 \\
\hline
\end{tabular}

Fig.1 Flow discharge pattern of wastewater from a Typical Tanning Unit. Processing E.I to finish and wet blue to finish of producing capacity $2000 \mathrm{Kg}$

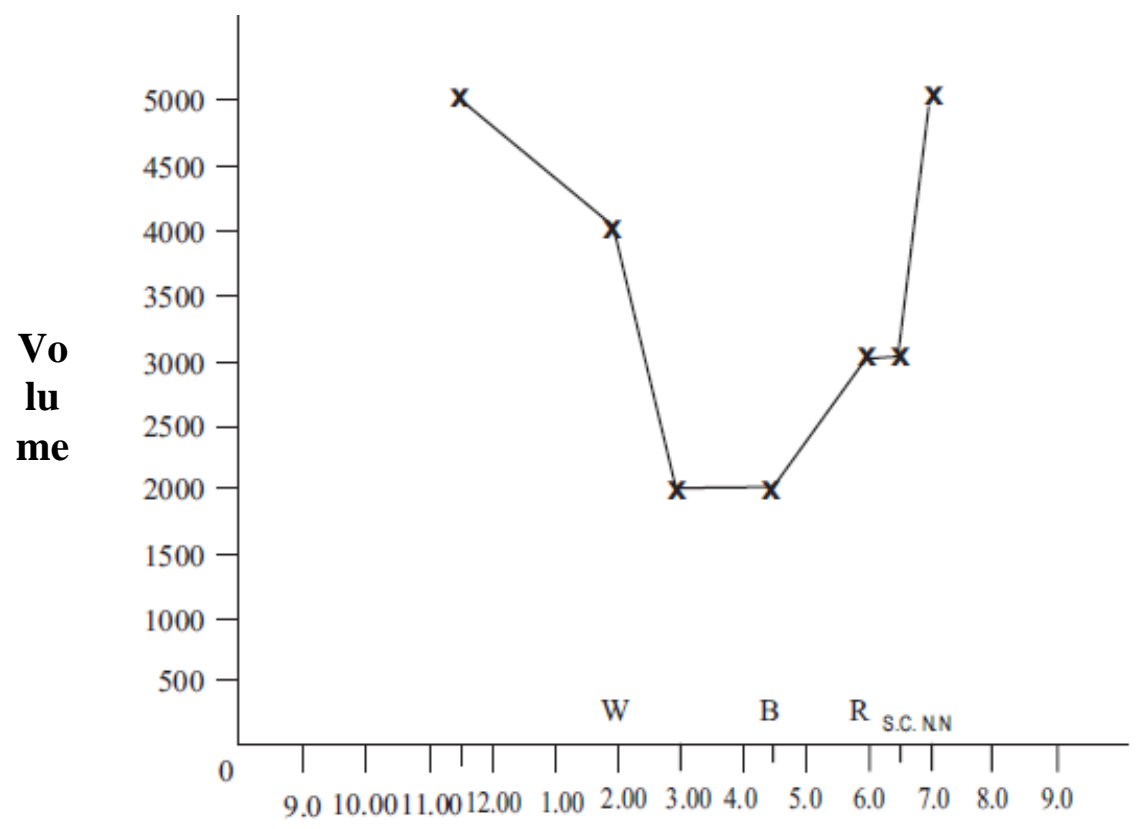

Time 
Fig.2 Schematic Diagram for Treatment of Tannery Wastewater

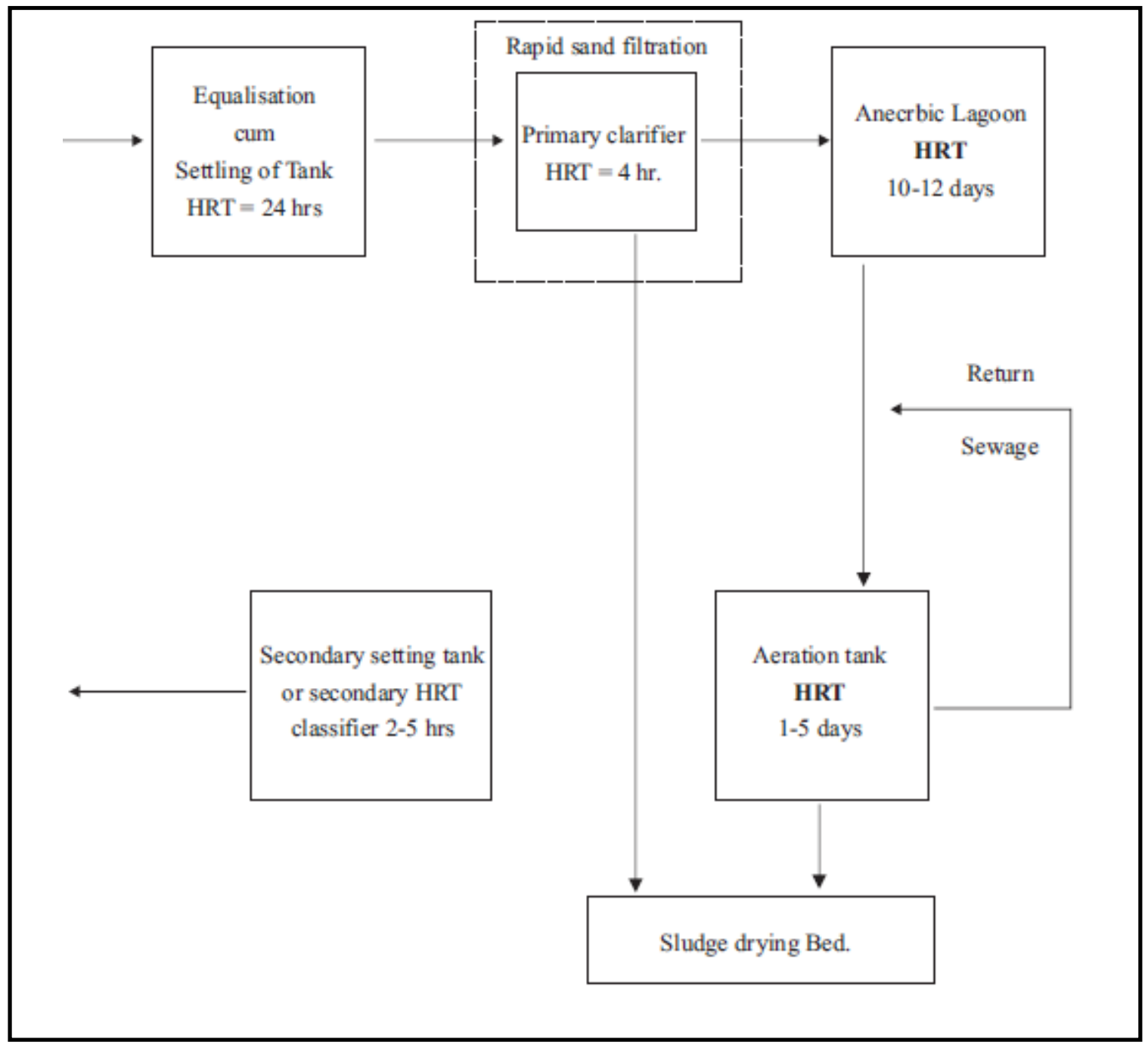

\section{Equalization cum settling tank}

As already pointed out that wastewater from tanning unit is discharged intermittently due to batch operations involved. Thus $\mathrm{pH}$ of wastewater fluctuating within a wide range, and organic load is also shifted from the average value to a greater extent. Equalisation cum settling tank is provided with the idea to equalize the strength and to maintain steady flow to the Biological treatment unit. This is done to prevent them from slow load application.

\section{Primary Clarifier}

Certain wastes like Wet blue to finish, crusts to finish are acidic in nature. Hence these wastes are adjusted to desired $\mathrm{pH} 7.8$ by using lime. The $\mathrm{pH}$ of waste water from Raw to Wet blue and Raw to Finish are too far from 7.0. In such cases, the $\mathrm{pH}$ is brought to normal $\mathrm{pH}$ by adding alum. The calculated quantum of coagulants is mixed with wastewater, until the desired $\mathrm{pH}$ is reached and is flocculated at low r.p.m. Many abiotic factors can influence the rate of degradation in soil such as $\mathrm{pH}$, Redox conditions and organic matter (Jensen 1996).

The detention time used for primary clarification is 24 hrs. Then the supernatant is pumped to biological treatment unit.

Biological treatment includes Anaerobic and Aerobic processes. Anaeobic treatment is used for high strength wastewaters while aerobic treatment process is used for low strength wastewaters.

(Sekaran et al., 1996).Anaerobic digestion of complex organics can be described as a three-stage process - 
Hydrolysis, liquefaction and fermentation

Hydrogen and acetic acid formation and

Methane formation

Hydrolysis and liquefaction are accomplished by extracellular hydrolysis for this specific purpose. It is significant to note that the stabilization of complex organic material depends upon its initial hydrolysis step. The overall rate of stabilization and methane formation can be controlled by the rate of hydrolysis of complex organics. Hydrolysis reaction of complex organic material is closely followed by formation of propionic, butyric and valic ${ }^{9,10,11,12}$ acids. Hydrogen is produced by fermentative bacteria and acetogenic bacteria. (Wiemann, MH.Schenk and W. Hegemann,1998). Regarding methane formation the conversion of acetic acid into methane is of prime importance in waste stabilization. Acetic acid and hydrogen serve as the major substrates for methane formation in the anaerobic digestion of wastewater sludges. Major portion of methane is formed as a result of acetate cleavage.

\section{$\mathrm{CH}_{3} \mathrm{COOH}$---------> $\mathrm{CH}_{4+} \mathrm{CO}_{2}$}

Different anaerobic treatments are available

Anaerobic lagoon

Anaerobic contact filter (downflow and upflow)

Upflow Anaerobic Sludge Blanket (USAB)

Aerobic Process includes -Trickling filter-Rotating biological contact filter-Activated sludge processOxidation ditch.

The Schematic diagram shows the movement of wastewater through different units in the treatment of tannery wastewater.

About $13 \%$ of the world's leather output comes from India. About 23 million people are employed in leather and leather related industries. In the chemical tanning process, as many as 250 chemicals are used, including heavy metals such as cadmium, arsenic and chromium.

A significant part of the chemicals used in leather processing is not actually absorbed or consumed in the process and hence it is discharged into the environment. Due to industrial enlargement, huge amounts of industrial wastes are accruing in the environment and can't be disposed (Belay, A.A., (2010). Liquid effluents from light leather processing comprises about 10 to 100 $\mathrm{mg} / \mathrm{L}$ of organic matter,chromium, sulphide, and solid waste including fleshing, trimmings, shavings and, buffing dust (Cheng, Y., F. Yan, (2010). About $60 \%$ of the total chromium salts react with the hides and about $40 \%$ of the chromium amount remains in the solid and liquid wastes Lofrano, G., S, 2013. Bidut et al.,(2013) investigated that $\mathrm{Cr}$ is hazardous to human wellbeing, beasts and the surroundings. Chromium is used in large amounts and the chromium in tanning wastes spreads into the whole environment. Martin et al., (1982) It is relatively immobile and insoluble substance and does not decompose but accumulates in the soil. Here chromium salts are entrained in the sludge creating serious problems for their disposal (Gauglhofer 1986). Tannery workers and people living close to tanneries experience certain specific health problems, presumably caused by contamination by the effluents. There is a high incidence of skin diseases and respiratory disorders. High abortion rates and menstrual disorders are common. Thus it can be emphasized that it would be fair to implement new cleaner technologies to reduce organics in treated waste water to trace level. Historically the tanning industry has tended to deal with new constraints by a single targeted response for (eg) compliance with chromium in effect was solved by transferring it to the sludge. Chrome recovery and reuse. (Rajamani et al., 1992).

\section{References}

APHA, 1998. Standard methods for the examination of water and waste water. APHA-AWWAWPCF.Washington D.C.

Biddut, C. S., and et al., 2013. Chromium effects of tannery waste water and appraisal of toxicity strength reduction and alternative treatment. International Journal of Agronomy and AgricultureVol. 3, No. 11, p. 23-35.

Bouwer et al., 1994. Degradation of xenobiotic compounds in situ: Capabilities and limits FEMS Microbiol Rev. 15: 307-317.

Chang AC, et al., 1984. Accumulation of heavy metals in sewage sludge treated soils. Journal of Environmental Quality 13, 87-91.

Cheng et al., 2010. Bioremediation of $\mathrm{Cr}$ (VI) and immobilization as $\mathrm{Cr}$ (III) by Ochrobactrumanthropi. Environmental Science and Technology. 44: 6357-6363

Gauglhofer J (1986) Environmental aspects of tanning with chromium. J.Soc. Leather Technol. Chem. 70 (1): 11 .

Hafez AIEI -Manharawy MS and Khedr MA 2012 RO membrane removal of unheated chromium spent 
tanning effluent. A pilot study, Part 2. Desalination 144: 237-242.

Haydar S.J.A. Aziz and M S Ahmad, 2007. Biological treatment of Tannery wastewater using activated sludge process. Pak. J. Eng. Applied Sci. 1: 61-66

Jensen J, 1996. Chlorophenols in the terrestrial environment. Rev. Environ ContamToxicol. 146: 25- 51.

Kadam, R V, 1987. Treatment of tannery wastes. Indian Journal of Environmental Protection, 10 (3), 212216.

Kannan et al., 2012. Bioremediation of Tannery Effluents by Diazotrophiccyanobacterium, Tolypothrixtenuis (Kuetz.) Schmidt em. World Rural Observations 4(1), 56-60.

Lofrano, G., S. et al., 2013.Chemical and biological treatment technologies for leather tannery chemicals and wastewaters. Science of the Total Environment. 461-462: 265-281
Martin, M H et al., 1982. Biological monitoring of heavy metal Pollution In: Land and Air. Applied Science Publishers, London.

Rajamani, et al., 1992. Chrome recovery and reuse in India In: Water Environment and Technology.

Ros M, Ganter A (1998) Possibilities of reduction of recipient loading of tannery waste. Slovenia.Water Sci Tech. 37: 145-152.

Sekaran et al., 1996. Removal of sulphide in anaerobically treated tannery wastewater by wet air oxidation. J. Environ. Sci. Health A. 31: 579-598.

Vijayanand et al., 2012 et al., Studies on the Bioremediation of Chromium (VI) Through Bioleaching by Thiobacillusferrooxidans. Int. Journal of Research in Environmental Science and Technology 2(3), 54-60.

WiemannM, H. et al., 1998. Anaerobic treatment of tannery wastewater with simultaneous sulphide elimination. Water Res: 32: 774-780.

\section{How to cite this article:}

Rita Jayaraj. 2017. An Overview of Environmental Pollution Management in Tanning Unit. Int.J.Curr.Res.Aca.Rev. 5(9), 1-9. doi: https://doi.org/10.20546/ijcrar.2017.509.001 